\title{
TRAINING IN THE BRITISH CIVIL SERVICE
}

\author{
by \\ F. J. Tickner, C. B. E.
}

Mr. Tickner is Deputy Director of

Public Administration in the Technical Assistance Administration of the United Nations. Until June 1952 he was Director of Training and Education in the British Civil Service

The organization of training in the British Civil Service follows the same pattern as all other matters affecting personnel. Each ministry is responsible for its own training arrangements, but these arrangementis are coordinated by the Treasury, the ministry which has the responsisibility for general coordination of personnel matters throughout the service.

Each ministry (which in the United Kingdom is usually called a Department) has its own Departmental Training Officer. He is responsible to the principal personnel officer for the training arrangements of the Department. At the same time there is at the Treasury a Director of Traning and Education who is responsible for the general guidance and control of training throughout the Civil Service as a whole. By means of regular meetings of departmental training officers with the Director of Training and Education as Chairman to discuss general problems, and by correspondence on specific matters between the Departments and the Treasury, a general training policy is evolved and maintained.

This arrangement allows for a measure of variation between one Department and another to meet their individual requirements. Departments vary considerably in size and in the variety of their functions. The Board of Inland Revenue, for example, with a staff of nearly 50,000 is engaged primarily with the assessment and collection of direct taxation; in spite of its size, it function is therefore relatively narrow in scope. The Treasury, on the other hand, has a small staff of less than 2000 with a very wide varitey of functions, including financial po- 
licy, government loans, capital investment problems, economic planning; international monetary questions, currency exchange, issue of coinage and paper money, government expenditure, organization and methods, civil service salary and wage regulation, conditions of employment in the Civil Service and general problems of personnel.

As a rule training for new entrants to the Service follows one or both of two methods; class-room instruction and learning by performing actual work under guidance. The more varied functions of the Department the less possible it becomes to organize class instruction because of the variety of tasks to which individual members of any one group of trainees will be assigned. In each Departmene there is usually an initial course of general class instruction for all newcomers. A group of new entrants (twelve is usually regarded as the ideal size for a group) will be given a series of general talks about the function of their Department and its place in the structure of government. This will be supplemented bu sessions on the parliamentary system as it effects the Civil Service, and on the duties of the individual civil servant.

This introductory course may last a week or a fortnight. It gives the new recruit a general idea of the Department in which he or she is going to work and he has an opportunity of making friends with a few at any rate of the other newcomers. Then he is assigned to a section of the Department, usually ith some regard to his personal aptitudes. A recruit who shows ready adaptability in his dealings with other people may find his way to a section where interviews with members of the public are part of the normal routine; a recruit with aptitude for mathematics may go to the accounting section.

Wherever he goes the newcomer will have someone designated as directly responsible for his guidance and tuition. It may be a supervisor who has special aptitude for instruction, or it may be a senior colleague with good experience of the work. Within his first two years of service he will be given a change of duty so that his ability can be judged from the impression which he makes in two entirely separate sections of the Department, with quite different supervisors. If his first assignment proves to be unsuitable the change to fresh work will be made more quickly; if any doubt of his capabilities remains after two assignments he may be given a third.

In some Departments the Training Officer continues to be responsible for the newcomer during this period of probation; more 
usually someone in the personnel section watches the progress of the recruit, by means of interviews and of reports from the working supervisors, with the advice of the Training Officer where necessary.

In a Department where the work has less variation and where there are large groups of staff performing similar functions, it is possible to continue training in the schood for a longer period. In the Post Office, for example, telephone operators and the clerks responsible for the public counters remain at the training school for six or eight weeks and take up duty when tests have shown that they are reasonably proficient in their new work. Instruction is given by demonstration, by discussion, or by question and answer, rather than by lecturing.

In the postal school, there are model offices, organized and equipped with counters exactly like the real ones, where some of the students, or the instructors, take the place of customers and the trainees in turn have to meet their requirements or answer their enquiries, exactly as if they really were members of the public.

In the telephone school the students sit at special positions at the switchboard in the working office. There is an instructor seated between every two students. At first she supervises the way in which they begin to take real calls from the public, until finally they are able to take over working load without help from the instructor.

So far we have dealt with staff performing work peculiar to one Department. There are a number of people who are required to undertake tasks common to a number of Departments and it is more convenient to train them by means of central courses, which are given at the Treasury.

One of the most important of these is the course of the instructors, who themselves give training in the various Departments. Each new instructor goes to the Treasury to study the technique of instruction, After a number of sessions on teaching methods and after demonstration lessons by Treasury instructors, each student has to prepare and give three practice lessons with fellow students acting as pupils. In this way all instructors throughout the service learn to follow the same teaching methods.

The increasing complexity of modern government makes it necessary for the more senior civil servants to be entirely familiar with the central machinery of government and with operations of Departments other than their own. Therefore new entrants to the administra- 
tive staff attend a short general course in addition to the training which is given to them in their own Department. These administration recruits enter the service direct from the university or are selected, before reaching the age of thirty, from amongst the more promising members of more junicr grades. They recoive a broad training, lasting several months, in the work of their Department, and are given opportunities of making special visits to see all phases of its work both at Headquariers and in its subordinate offices.

After they have been in training for about six months they are brought to the Treasury in groups of sixteen, drawn from a variety of Departments, to etudy the mechinary of government, the relationship between the Civil Service and Parliament and the work of certain selected Departments, such as the Ministry of Education or the Department of Scientific and Industrial Research. At this course the instruction is given by means of informal talks by civil servants from the appropriate Departments, who give their services voluntarily and describe work which they themselves actually perform. A number of these speakers are amongst the most distinguished members of their profession. Heads of Dspartments, the Secretary of the Cabinet, senior members of the Treasury and several Ministers have given talks at these courses.

The students learn to appreciate the intimate relationship between the work of one Department and another, and the best means of securing effective cooperation between the various parts of the governmental system. During their careers members of the administrative staff are likely to be transferred, as part of their normal experience, from one Department to another and they are therefore encouraged from the beginning to feel that they are members of the Service as a whole, and that they have wider interests than those of their individual Department.

For newcomers of all ranks throughout the Service the training is designed to make each one feel that he is a member of a team and that he has been appointed to a Department in which he will be proud to serve. He is also shown that he has wider loyalties, that all members of Her Majesty's service are engaged on a common task, whatever thei: individual functions may be.

Each civil servant has also to appreciate that he is a servant of the community as a whole, and that his duties call for a high standard 
of performance. Every member of the British Civil Service accepts the most exacting requirements of personal integrity in the performance of his duty. He must also give to every member of the community, with whom he comes into contact, the most scrupulously fair treatment, and he must on no account show favour to anyone. The humblest citizen who calls at the office must be given the same careful and courteous attention as the most distinguished member of the local community. The need for this attitude of helpfulness, both in dealing with visitors to the office and in written correspondence with the public, is emphasized in the training courses of every Department. The days are long since past when an official could keep his callers waiting outside his office or could send to his correspondents obscure letters written in an involved official style.

The Civil Service also encourages its staff to pursue studies in other fields than in their departmental work. For many official tasks further education, beyond what may have been received at school or university, is both useful and desirable. Some boys or girls who were unable to continue their formal education beyond the age of sixteen, may wish to study in order to sit for examinations, arranged by the Civil Service Commission, which give them access to grades more specialized or in some instances more senior, than the one in which they are serving. For specialists like engineers, architects, scientists or accountants, there are professional qualifications to be achieved by examination, additional university qualifications which can be gained even if the student is not free to attend whole-time courses at college. Wherever further education of this kind increases the professional competence and ability of the individual, every encouragement is given to it, even to the extent of limited facilities for study in official hours. Where further education tends only to the better enjoyment of leisure hours (and a good many evening classes at institutions in the United Kingdorn have this as their primary objective), civil servants are encouraged to attend, but they are not allowed to do so their working hours.

These developments in Civil Service training are not entirely new. Some of the departmental training schemes and many further educational programmes date from the period between the wars; but the organization of training as a separate function of the personnel administration is an innovation within the last ten years. A similar dom during the same period. 
In 1952 the Government appointed a committee, of which Sir Ralph Assheton, then Financial Secretary to the Treasury, was chairman to examine the whole question of the training of civil servants. Its report, dated May 1944, proposed the appointment of the Director of Training and Education and of the Departmental Training Officers, and its recommendations, most of which have been adopted, have given $\mathbf{a}$ great impetus to more general and systematic development of training throughout the Civil Service of the United Kingdom. 